\title{
Long-Term Forest Dynamics and Land-Use Abandonment in the Mediterranean Mountains, Corsica, France
}

\author{
Almudena San Roman Sanz ${ }^{1}$, Catherine Fernandez ${ }^{2}$, Florent Mouillot ${ }^{3}$, Lila Ferrat $^{1}$, Daniel Istria ${ }^{4}$ and Vanina Pasqualini $^{1}$
}

\begin{abstract}
Human practices have had an impact on Mediterranean ecosystems for millennia, particularly through agricultural and pastoral activities. Since the mid-19th century, land-use abandonment has led to the expansion of shrubland and forest, especially in the mountainous areas of the northern Mediterranean basin. Knowledge of these factors is vital to understanding present forest patterns and predicting future forest dynamics in the Mediterranean mountains. We aimed to analyze and understand how land-use abandonment affected spatial modifications of landscapes in two study areas, 44,000 ha and 60,000 ha, located on the island of Corsica, France, representing a typical Mediterranean environment with chestnut forests. Our approach used land-cover archive documents from 1774, 1913, 1975, and 2000, and human population history, 1770 to present day, to describe landscape patterns following land-use abandonment. This research showed that dramatic changes in landscape at the two study areas were caused by the suspension of human influence and the interruption of traditional farming practices. Over the study period, both study sites showed significant reforestation of shrubland and cultivated areas marked by the presence of Quercus ilex forests ( $+3.40 \%$ yr-1 between 1975 and 2000) and by Pinus pinaster ( $+3.00 \%$ yr-1 between 1975 and 2000) at one study site that had experienced heavy rural exodus. At the same time, areas containing chestnut forests decreased by $50 \%$ between 1774 and 2000 (-0.09\% yr-1 between 1774 and 1975 and -1.42\% yr-1 between 1975 and 2000). Shrubland expansion remained limited at both study sites. Our study highlights the value of small-scale approaches for understanding the ecological consequences of land-use abandonment and present and future land-management decisions. Discussion concludes on the importance of working with long-term series for studies on resilience in social-ecological systems and on the consequences in terms of provision of ecosystem services.
\end{abstract}

Key Words: historical archives; human population; landscape patterns; land-use change; Mediterranean ecosystems

\section{INTRODUCTION}

The abandonment of agricultural land has been a widely observed trend in the Mediterranean mountains since the early 19th century (Walther 1986, Garcia-Ruiz and LasantaMartinez 1990, Blondel and Aronson 1999, MacDonald et al. 2000, Romero-Calcerrada and Perry 2004). The commercialization of agriculture through technological development combined with increasing off-farm employment opportunities arising from the industrialization and urbanization of accessible lowland areas has motivated many mountain farmers to migrate, either temporarily or permanently. Depopulation and land abandonment essentially reflect an inability to enhance the productivity of traditional agriculture because of fragile mountain environments, reduced economies of scale because of highly fragmented and diversified biophysical conditions, and resistance to the adoption of modern, market-oriented farming practices (MacDonald et al. 2000). Land-use changes are the main processes shaping land-cover variation, ecosystem dynamics, and shifting landscape patterns.

The re-establishment of natural species on abandoned agricultural land is a common land-use change in the northern rim of the Mediterranean basin (Debussche et al. 1999, Mouillot et al. 2005, Chauchard et al. 2007) and has led to the expansion of scrub and forest and a decrease in many seminatural open habitats in the Mediterranean mountains that had previously been maintained by traditional practices (Marty et al. 2003). The intensity of this mountain area revegetation has had several negative consequences, including greater risk of fire and an increase in the speed at which wildfires spread (Vázquez and Moreno 1998), reduced water availability (Gallart and Llorens 2004), a reduction in landscape quality and agricultural value (Vos and Meekes 1999), a reduction in the extent of pastoral areas (Molinillo et al. 1997), and a reduced spatial distribution of rare or endemic species (Farina 1997, Preiss et al. 1997, Labaune and Magnin 2002, Kiss et al. 2004).

In this context, Europe's regional administrations have introduced specific measures to promote the regeneration of these lands, i.e., prevent abandonment and facilitate forest restoration (Pereira et al. 2005, Lasanta et al. 2009). Sustainably managing these lands requires a historical understanding of the chronology and mechanisms shaping woodland expansion to support targeted regional planning. The main goal of such planning is to evaluate landscape dynamics at appropriate spatial and temporal scales, giving special focus to factors and processes that influence landscape change. It is necessary to analyze the socioeconomic changes that have occurred since the 18 th century to estimate their

\footnotetext{
${ }^{1}$ Université de Corse, Sciences Pour l'Environnement, ${ }^{2}$ Aix-Marseille Université, Institut Méditerranéen de Biodiversité et d'Ecologie (IMBE), ${ }^{3}$ DREAM CEFE/CNRS, France, ${ }^{4}$ Aix-Marseille Université, Laboratoire d'Archéologie Médiévale et Moderne en Méditerranée, Maison Méditerranéenne des Sciences de l'Homme
} 
influence on present-day forest cover and dynamics (Agnoletti 2007). Proper analysis of ecosystem dynamics hinges on using local land-use and socioeconomic history.

Few studies have attempted to analyze and understand the interactions between historical spatial changes and land-use abandonment in Mediterranean landscapes because of the scarce data available. Understanding these interactions would help clarify unresolved questions on the interrelated effects of land abandonment and long-term Mediterranean vegetation dynamics. This study set out to find answers by rebuilding land-cover dynamics and land-use abandonment through human population history over a period long enough to reflect on both land-use changes and intrinsic successional processes. Two study areas, located on the island of Corsica, France, Mediterranean Sea, (Fig. 1) were considered in relation to chestnut presence and to the populations involved. These two sites were similar in area, elevation, relief, and climate, but different in terms of landscape and population activity. The first site, San Petrone massif, is characterized by large chestnut groves and a high population density. The second site, VicoEvisa region, has more pastoral activity and a low population density. Both sites have experienced a significant decline in population since the last century.

Fig. 1. Location of Corsica in the western Mediterranean region. The study areas (black lines) are indicated on the topographical map.

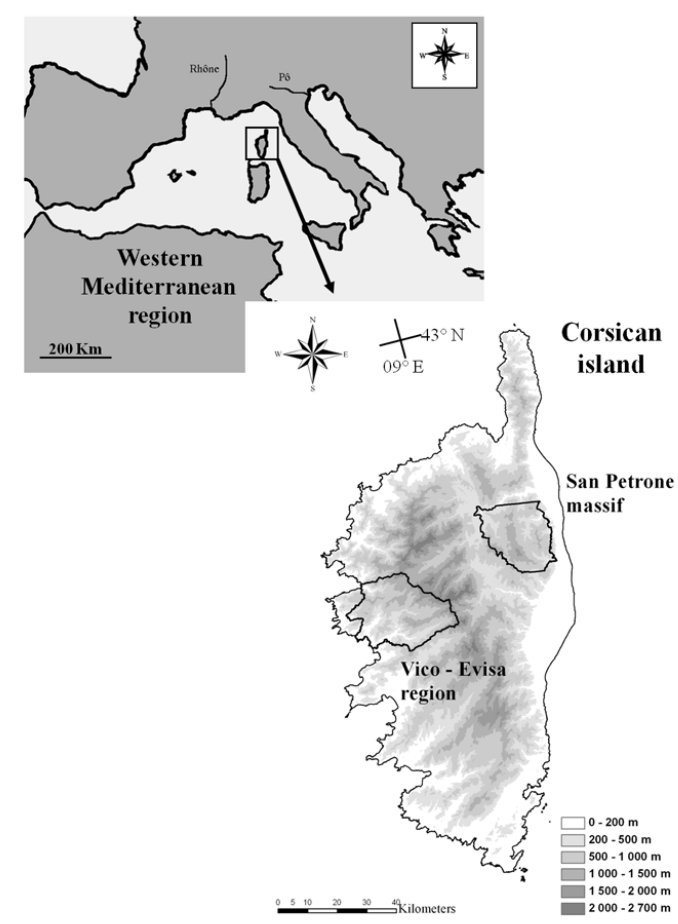

\section{MATERIAL AND METHODS}

\section{Study areas}

The study was performed on the island of Corsica, which is located in the western part of the Mediterranean region. Corsica is the woodiest island of the Mediterranean Sea, with forests covering $46 \%$ ( $401,817 \mathrm{ha}$ ) of the island's total 872,608 ha area (Inventaire Forestier National 2006). The topographic, geological, and climatic conditions, together with the influence of the sea, facilitate the installation of vegetation, resulting in forests that are frequently dense. Corsica is part of the Mediterranean climate zone with subtropical, temperate, or alpine affinities depending on season and altitude. Corsica's highly mountainous terrain produces significant climactic contrasts. The dominant species are the maritime pine (Pinus pinaster Ait.), holm oak (Quercus ilex L.), chestnut (Castanea sativa Mill.), Corsican pine (Pinus nigra Arn. ssp. laricio (Poir.) Maire var. corsicana), beech (Fagus sylvatica L.), and cork oak (Quercus suber L.; Inventaire Forestier National 2006). Two study areas were selected, San Petrone massif and the Vico-Evisa region (Fig. 1), similar in area, elevation, relief, and climate, but different in terms of landscape (Table 1). However, in both areas, chestnut trees have an impact on the local population's activities.

\section{Historical land-cover reconstruction}

The first map of Corsica, Plan Terrier, was ordered in 1774 by Louis XV of France to inventory the natural resources of the island after its acquisition (Caratini 1995). A precise map at a 1:10,000 scale was consequently published (Albitreccia 1942). The Archives départementales de Corse du Sud delivered six scanned maps for the two study areas. Each map was georeferenced using ArcGis version 9.3 (ESRI®). Confluence and ridge lines were used as basepoints for georeferencing the map with Lambert 4 coordinates; for each scanned map, 20 basepoints were used on the whole landscape. Land-cover patches are represented by polygons on a schematic topographic background. The polygons were redrawn in vector format by tracing the lines of the scanned and georeferenced maps. For San Petrone massif, each polygon was assigned to one of seven land-cover types used in the map (Table 2). For the Vico-Evisa region, each polygon was assigned to 1 of 13 land-cover types used in the map, which correspond to combinations of the 7 land-cover types in the Plan Terrier (Table 2). We aggregated woodlands and chestnut forests into a generic 'forests' land-cover type, and olive trees, vineyards, and crop cultivations into a generic 'cultivated areas' land-cover type. We consider the four generic land-cover types, forests, shrublands/grasslands, cultivated areas, and urban areas, used as a common classification for long-term translation across time (Table 2). The maps were converted to raster format at a 100-m resolution in a GIS database. 
Table 1. General characteristics of the two study areas.

\begin{tabular}{|c|c|c|}
\hline Study areas & San Petrone massif & Vico-Evisa region \\
\hline Geographical coordinates & $42^{\circ} 19^{\prime} \mathrm{N}, 9^{\circ} 20^{\prime} \mathrm{E}$ & $42^{\circ} 12^{\prime} \mathrm{N}, 8^{\circ} 46^{\prime} \mathrm{E}$ \\
\hline Surface area (ha) & 43,875 & 60,409 \\
\hline Elevation (m) & $\begin{array}{l}80 \text { to } 1767 \\
\text { ( } 40 \% \text { of the study area is between } 500 \text { and } 700 \mathrm{~m} \text { ) }\end{array}$ & $\begin{array}{l}0 \text { to } 2200 \\
\text { ( } 40 \% \text { of the study area is between } 400 \text { and } 900 \mathrm{~m} \text { ) }\end{array}$ \\
\hline Climate & $\begin{array}{l}\text { Mediterranean mountain } \\
\text { (warm and dry in the summer / cold and snowy in winter) }\end{array}$ & $\begin{array}{l}\text { Mediterranean mountain } \\
\text { (warm and dry in the summer / cold and snowy in winter) }\end{array}$ \\
\hline $\begin{array}{l}\text { Mean annual } \\
\text { precipitation }(\mathrm{mm})\end{array}$ & $\begin{array}{l}942 \pm 326 \\
\text { (according to the Piedicrocce meteorological station [1952- } \\
1976] \text { and the La Porta meteorological station [1977-2008]) }\end{array}$ & $\begin{array}{l}1271 \pm 310 \\
\text { (according to the meteorological station at Evisa [1955- } \\
2008] \text { ) }\end{array}$ \\
\hline $\begin{array}{l}\text { Mean annual } \\
\text { temperature }\left({ }^{\circ} \mathrm{C}\right)\end{array}$ & $\begin{array}{l}12.7 \pm 1.3 \\
\text { (from 5.2 in January to } 21.4 \text { in August) } \\
\text { (according to the meteorological station [1980-2008]) }\end{array}$ & $\begin{array}{l}12.5 \pm 0.9 \\
\text { (from 5.7 in January to } 22.4 \text { in August) } \\
\text { (according to the meteorological station [1978-2008]) }\end{array}$ \\
\hline Substrate & $\begin{array}{l}\text { Schist associated with rocks of oceanic origin } \\
\text { (Durand-Delga 1978) }\end{array}$ & $\begin{array}{l}\text { Granite covered by brown acid soils } \\
\text { (Roche and Roux 1976) }\end{array}$ \\
\hline $\begin{array}{l}\text { Landscape at the } \\
\text { highest altitude }\end{array}$ & $\begin{array}{l}\text { Fagus sylvatica pure and sometimes mixed with Pinus laricio } \\
\text { or Pinus pinaster in the western massif border (Gamisans } \\
\text { 1999) }\end{array}$ & $\begin{array}{l}\text { Pinus laricio pure and sometimes mixed with Fagus sylvatica } \\
\text { or Pinus pinaster in the lower fringe } \\
\text { (Gamisans 1999) }\end{array}$ \\
\hline $\begin{array}{l}\text { Landscape at the } \\
\text { lower altitude }\end{array}$ & $\begin{array}{l}\text { Castanea sativa (introduced by humans; Pitte 1982, 1986) } \\
\text { often mixed with Alnus cordata, Quercus ilex, moors, } \\
\text { scrubland (e.g., Cistus sp., Pteridium sp., Laburnum sp.; } \\
\text { Gamisans 1999) }\end{array}$ & $\begin{array}{l}\text { Scrublands (e.g., Cistus sp., Pistacia lentiscus, Myrtus } \\
\text { communis) and grasslands with scattered Quercus ilex or } \\
\text { Pinus pinaster. Castanea sativa fairly common in this area } \\
\text { with moors and ferns (Pteridium sp.). Valleys and littoral- } \\
\text { zone coasts with different crops (Gamisans 1999) }\end{array}$ \\
\hline
\end{tabular}

An additional survey was conducted on the territory by the French fiscal services (Source: Archives départementales de Haute-Corse et de Corse du Sud; Corvol 1999). This survey provided landscape compositions for the year 1913, but in a nonspatial format. We used this for intermediate updates of landscape composition. We consider the four generic landcover types as the common classification for long-term translation across time.

\section{Present land-cover maps}

Amandier et al. (1984) established a precise land-cover map of Corsica for 1975. Each map was built from 1:17,000 scale, color-infrared aerial photographs. Numerical vector maps with Lambert 4 coordinates were provided by Corsica's regional environment office. We assigned vegetation types to the remaining polygons, and 12 land-cover types were defined according to a vegetation layer-based typology developed by Godron et al. (1968) and Trabaud (1973) for Mediterranean vegetation (Table 2). Chestnut forests, coniferous forests, beech forests, mixed forests, riparian forests, and other broadleaf forests corresponded to dense or open forests with trees (height $>2 \mathrm{~m}$ ) covering between $25 \%$ and $100 \%$ of the area, as described in Table 2. As defined in the map key, we considered the vegetation type mixed forests, which included undifferentiated coniferous and broadleaf forests in which Castanea sativa or Fagus sylvatica could be present. Shrublands, mixed shrublands/grasslands, and grasslands corresponded to nonforested land-cover types and were defined according to percentage cover of shrubs and herbaceous layers (Table 2). The vegetation types were aggregated into the four generic land-cover types for certain analyses (Table 2). The maps were converted to a $100 \mathrm{~m}$ resolution raster format in a GIS database.

The National Forest Inventory established a precise land-cover map of Corsica for the year 2000 (Inventaire Forestier National 2006), built from 1:17,000 scale, color-infrared aerial photographs. Numerical vector maps with Lambert 4 coordinates were produced. We assigned vegetation types to the remaining polygons, and 12 vegetation types were defined according to a vegetation layer-based typology for Mediterranean vegetation (Godron et al. 1968, Trabaud 1973; Table 2). In the National Forest Inventory, chestnut forests, coniferous forests, beech forests, mixed forests, undifferentiated broadleaf forests, and other broadleaf forests corresponded to dense and open forests with $40 \%$ to $100 \%$ tree cover (Table 2). As defined in the National Forest Inventory legend, we considered mixed forests, which included undifferentiated coniferous and broadleaf forests, and undifferentiated broadleaf forests, all the broadleaf species in which Castanea sativa or Fagus sylvatica could be present. Shrublands, mixed shrublands/grasslands, and grasslands corresponded to nonforested land-cover types. Because this map had essentially been created based on the forest inventory, it did not define bare soils, cultivated areas, or urban areas. We assigned every polygon to these land-cover types using $1: 25,000$ scale, color aerial photographs that had been created by the Institut Géographique National in 2001. Polygon interpretation was therefore based on in situ field observations that were gathered in spring 2009. Using a GPS, we collected 149 field data points for the San Petrone massif and 122 field data points for the Vico-Evisa region to inventory maximum 
Table 2. Generic land-cover types, definitions, and percentage cover of each vegetation layer for each map used.

\begin{tabular}{|c|c|c|c|c|c|c|}
\hline $\begin{array}{l}\text { Generic } \\
\text { land-cover } \\
\text { type }\end{array}$ & $\begin{array}{l}1774 \text { (Plan } \\
\text { Terrier) }\end{array}$ & Definition & $\begin{array}{l}1975 \text { (Amandier } \\
\text { et al. 1984) }\end{array}$ & Definition & $\begin{array}{l}2000 \text { (Inventaire } \\
\text { Forestier } \\
\text { National, 2006) } \\
\end{array}$ & Definition \\
\hline \multirow[t]{7}{*}{ Forests } & $\begin{array}{l}\text { Chestnut } \\
\text { forests }\end{array}$ & Only Castanea sativa & Chestnut forests & $\begin{array}{l}\text { Dense and open forests of } \\
\text { Castanea sativa (tree layer } \\
>2 \mathrm{~m}=25-100 \% ; \text { shrub and } \\
\text { herbaceous layer }<2 \mathrm{~m}= \\
0-100 \% \text { ) }\end{array}$ & Chestnut forests & $\begin{array}{l}\text { Dense and open forests of } \\
\text { Castanea sativa } \text { (tree layer }>2 \mathrm{~m} \\
=40-100 \%)\end{array}$ \\
\hline & Woodlands & $\begin{array}{l}\text { Others forests (Coniferous } \\
\text { and broadleaf) }\end{array}$ & $\begin{array}{l}\text { Coniferous } \\
\text { forests }\end{array}$ & $\begin{array}{l}\text { Dense and open forests of } \\
\text { coniferous (tree layer }>2 \mathrm{~m} \\
=25-100 \% \text {; shrub and } \\
\text { herbaceous layer }<2 \mathrm{~m}= \\
0-100 \%)\end{array}$ & $\begin{array}{l}\text { Coniferous } \\
\text { forests }\end{array}$ & $\begin{array}{l}\text { Dense and open forests of } \\
\text { coniferous (tree layer }>2 \mathrm{~m}= \\
40-100 \% \text { ) }\end{array}$ \\
\hline & & & Beech forests & $\begin{array}{l}\text { Dense and open forests of } \\
\text { Fagus silvatica (tree layer }> \\
2 \mathrm{~m}=25-100 \% ; \text { shrub and } \\
\text { herbaceous layer }<2 \mathrm{~m}= \\
0-100 \% \text { ) }\end{array}$ & Beech forests & $\begin{array}{l}\text { Dense and open forests of Fagus } \\
\text { silvatica }(\text { tree layer }>2 \mathrm{~m}= \\
40-100 \%)\end{array}$ \\
\hline & & & Mixed forests & $\begin{array}{l}\text { Dense and open mixed } \\
\text { forests of coniferous and } \\
\text { undifferentiated broadleaf } \\
\text { (tree layer }>2 \mathrm{~m}=25-100 \% \text {; } \\
\text { shrub and herbaceous layer } \\
<2 \mathrm{~m}=0-100 \% \text { ) }\end{array}$ & Mixed forests & $\begin{array}{l}\text { Dense and open mixed forests of } \\
\text { coniferous and undifferentiated } \\
\text { broadleaf (tree layer }>2 \mathrm{~m}= \\
40-100 \% \text { ) }\end{array}$ \\
\hline & & & Riparian forests & $\begin{array}{l}\text { Dense and open riparian } \\
\text { forests (tree layer }>2 \mathrm{~m}= \\
25-100 \% ; \text { shrub and } \\
\text { herbaceous layer }<2 \mathrm{~m}= \\
0-100 \% \text { ) }\end{array}$ & & \\
\hline & & & & & $\begin{array}{l}\text { Undifferentiated } \\
\text { broadleaf forests }\end{array}$ & $\begin{array}{l}\text { Dense and open undifferentiated } \\
\text { broadleaf forests (tree layer }> \\
2 \mathrm{~m}=40-100 \% \text { ) }\end{array}$ \\
\hline & & & $\begin{array}{l}\text { Other broadleaf } \\
\text { forests }\end{array}$ & $\begin{array}{l}\text { Dense and open forests of } \\
\text { others broadleaf (tree layer } \\
>2 \mathrm{~m}=25-100 \% \text {; shrub and } \\
\text { herbaceous layer }<2 \mathrm{~m}= \\
0-100 \% \text { ) }\end{array}$ & $\begin{array}{l}\text { Other broadleaf } \\
\text { forests }\end{array}$ & $\begin{array}{l}\text { Dense and open forests of others } \\
\text { broadleaf (tree layer }>2 \mathrm{~m}= \\
40-100 \% \text { ) }\end{array}$ \\
\hline \multirow[t]{4}{*}{$\begin{array}{l}\text { Shrublands/ } \\
\text { grasslands }\end{array}$} & $\begin{array}{l}\text { Shrublands/ } \\
\text { grasslands }\end{array}$ & Shrublands and grasslands & Shrublands & $\begin{array}{l}\text { Shrublands (tree layer }>2 \mathrm{~m} \\
=0-25 \% ; \text { shrub layer }<2 \mathrm{~m} \\
=0-100 \% ; \text { herbaceous layer } \\
=0-25 \%)\end{array}$ & Shrublands & $\begin{array}{l}\text { Shrublands (tree layer }>2 \mathrm{~m}= \\
0-40 \% \text { ) }\end{array}$ \\
\hline & & & $\begin{array}{l}\text { Mixed } \\
\text { shrublands/ } \\
\text { grasslands }\end{array}$ & $\begin{array}{l}\text { Mixed shrublands/ } \\
\text { grasslands (shrub and } \\
\text { herbaceous layer }<2 \mathrm{~m}= \\
25-100 \% \text { ) }\end{array}$ & $\begin{array}{l}\text { Mixed } \\
\text { shrubland/ } \\
\text { grasslands }\end{array}$ & Mixed shrublands/grasslands \\
\hline & & & Grasslands & $\begin{array}{l}\text { Grasslands (shrub layer < } \\
2 \mathrm{~m}=0-25 \% ; \text { herbaceous } \\
\text { layer }=25-100 \% \text { ) }\end{array}$ & Grasslands & Grasslands \\
\hline & & & Bare soils & Bare soils, rocks, beach & Bare soils & Bare soils, rocks, beach \\
\hline \multirow[t]{3}{*}{$\begin{array}{l}\text { Cultivated } \\
\text { areas }\end{array}$} & Olive trees & Cultivated olive trees & Cultivated areas & $\begin{array}{l}\text { Orchards, vineyards, } \\
\text { herbaceous cultures, and } \\
\text { cultivated olive trees }\end{array}$ & Cultivated areas & $\begin{array}{l}\text { Orchards, vineyards, herbaceous } \\
\text { cultures, and cultivated olive } \\
\text { trees }\end{array}$ \\
\hline & $\begin{array}{l}\text { Cultivated } \\
\text { areas }\end{array}$ & Crop cultivations & & & & \\
\hline & Vineyards & Vineyards & & & & \\
\hline $\begin{array}{l}\text { Urban } \\
\text { areas }\end{array}$ & $\begin{array}{l}\text { Urban } \\
\text { areas }\end{array}$ & Urban areas & Urban areas & $\begin{array}{l}\text { Urban areas, Outer-urban } \\
\text { areas, gardens }\end{array}$ & Urban areas & $\begin{array}{l}\text { Urban areas, Outer-urban areas, } \\
\text { gardens }\end{array}$ \\
\hline
\end{tabular}


surface area covered by bare soils, cultivated areas, and urban areas. The vegetation types were aggregated into the four generic land-cover types for analysis (Table 2). The maps were converted to a $100 \mathrm{~m}$ resolution raster format in a GIS database.

\section{Land-cover analysis}

Temporal analyses were performed for the San Petrone massif and the Vico-Evisa region between 1774 and 1975 and between 1975 and 2000 using transition matrices in IDRISI ${ }^{\circledR}$ software. The transition matrices were obtained by crosstabulating the maps pixel by pixel. The cells above the diagonal represented areas that had reached a more advanced successional stage, whereas cells below the diagonal represented regression to an earlier successional stage.

Changes occurring between the earliest, 1774 , and most recent, 2000 , years were characterized and evaluated by generic landcover type and selected indices typically applied in landscape ecology. The items selected for the legend, after the evaluation to synthesize the main dynamics, were the following: no expansion and regression; forestation, i.e., shrublands/ grasslands, cultivated areas, and urban areas replaced with forest; shrubland expansion, i.e., forests, cultivated areas, and urban areas replaced with shrublands/grasslands; and anthropization, i.e., forests and shrublands/grasslands replaced with cultivated areas or forests, shrublands/ grasslands and cultivated areas replaced with urban areas. Maps charting these territory-scale dynamics were produced to enhance the understanding of the changes and their location in the studied areas.

\section{Human population history}

The human population history between the end of the 16th century and present day was assessed for every single municipality or village using the number of inhabitants by municipality, 72 municipalities in the San Petrone massif and 22 municipalities in the Vico-Evisa region. The population data used were as follows: (1) the review published by Casta (1993) for 1770 and 1787; (2) http://cassini.ehess.fr/cassini/ fr/html/6 index.htm for 1800 to 1954, at a frequency of about once every five years; and (3) French national statistics and economic studies agency (INSEE) data for 1962 to 1999, at a frequency of about once every seven to nine years.

Number of inhabitants per municipality versus time provided a proxy indicator for reconstructing agricultural history and land-use change. We linked this database with the spatial coverage exclusively concerning urban areas in the land-cover maps for the two study areas. This was performed to follow the evolution of inhabitant density, number of inhabitants per hectare in urban areas, at three time points, 1770, 1975, and 1999, corresponding to the available data on human populations in the years closest to the land-use change analysis.

\section{RESULTS}

\section{Changes in land-cover and landscape dynamics}

San Petrone massif

Forests were the predominant land-cover type, but they decreased from 1774 to 1913 and then increased from 1913 to 2000 (Fig. 2A). In 1774, these forests corresponded to chestnut forests, 39.2\%, and woodlands, $8.3 \%$ (Figs. 3A, 4). Chestnut forests were clustered around villages and particularly at elevations of $700 \mathrm{~m}$, while woodlands were situated in the center of the massif at higher elevations (>900 m). In 1975, forest had expanded to 57.8\% (Figs. 2A, 3A). This progression was mostly caused by an expansion of other broadleaf forests, $16.8 \%$ (Fig. 4). The chestnut forests decreased to $39.2 \%$ in 1774 and $31.9 \%$ in 1975, and transition matrices showed a regression of chestnut forests to shrublands and a transformation of chestnut forests to other broadleaf forests in 1975 (Fig. 4). In 2000, forests had increased to occupy $65.0 \%$ of the massif (Figs. 2A, 3A). The undifferentiated broadleaf forests are problematic for following the area of land-cover types. According to Inventaire Forestier National (2006), undifferentiated broadleaf forests included $40 \%$ chestnut forests and $60 \%$ other broadleaf forests on the massif. Extrapolating from this information, we calculated the area of chestnut forest in 2000 to be $20.6 \%$, which showed regression of chestnut forests to shrublands and

Fig. 2. Percentage cover of forests, shrublands/grasslands, cultivated, and urban areas in the San Petrone massif (a) and the Vico-Evisa region (b) from 1774 to 2000, according to the initial Plan Terrier map (1774), fiscal surveys (1913), and recent land-cover maps (1975 and 2000).
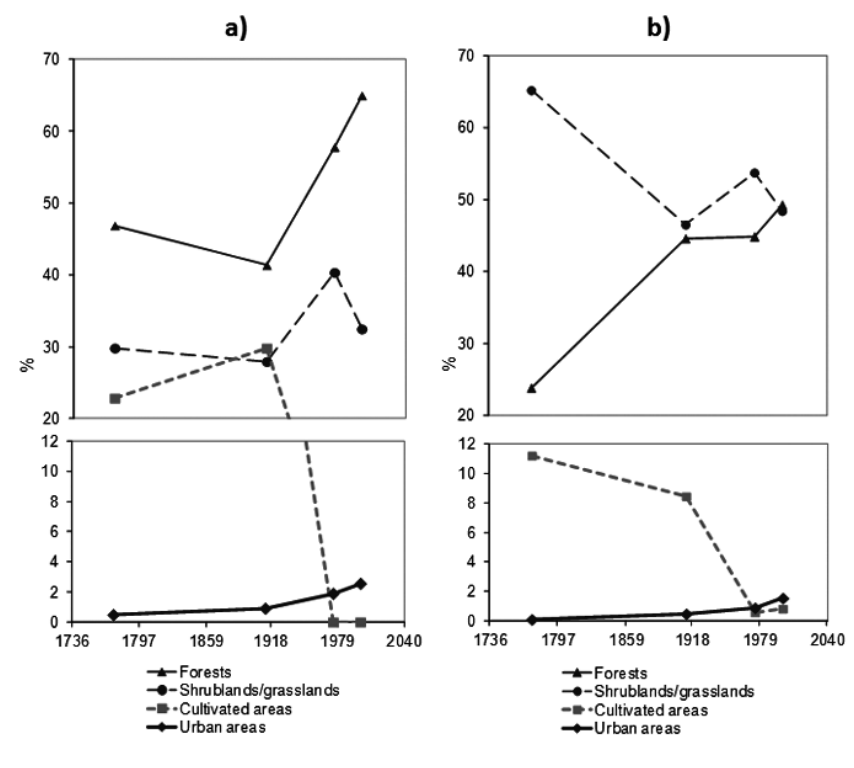
Fig. 3. Land-cover maps of the San Petrone massif (a) and the Vico-Evisa region (b) in 1774, 1975 , and 2000.

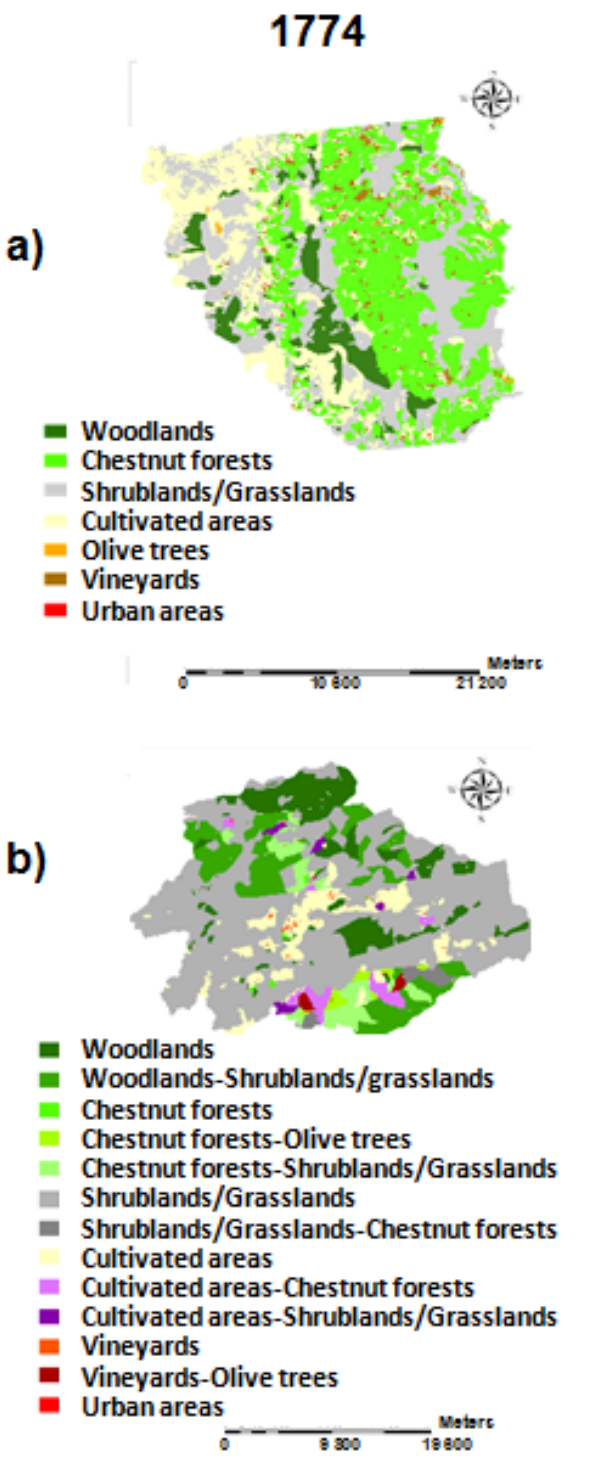

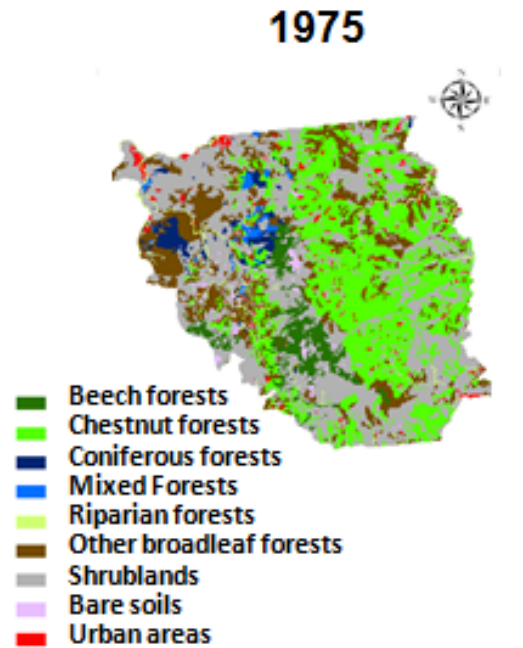
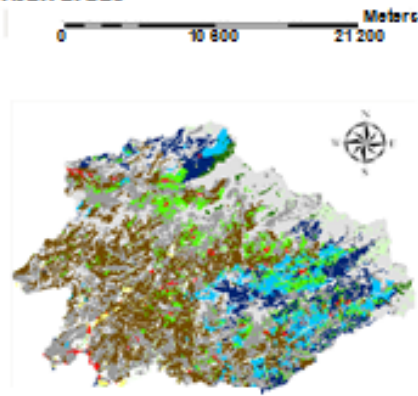

- Beech forests

- Chestnut forests

- Coniferous forests

- Mixed forests

Riparian Forests

- Other broadleaf forests

- Shrublands

- Shrublands/Grasslands

Grasslands

Bare soils

Cultivated areas

- Urbanareas

${ }_{0}-\longrightarrow 300-18900$
2000
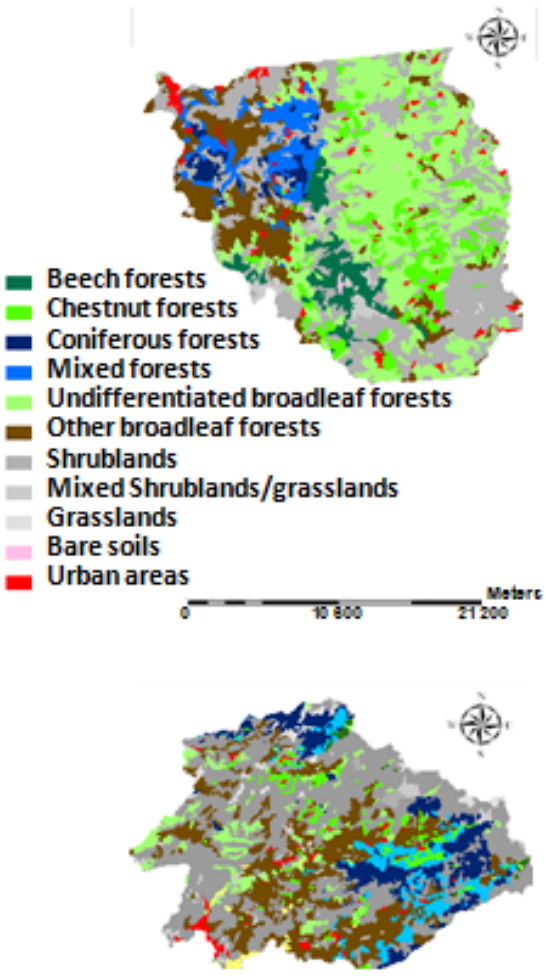

- Beech forests

- Chestnut forests

- Coniferous forests

- Mixed forests

Undifferentiated broadleaf forests

Other broadleaf forests

- Shrublands

Shrublands/Grasslands

Grasslands

Bare soils

Cultivated area

- Urbanareas

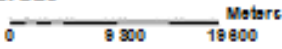

the transformation of chestnut forests to broadleaf forests (Fig. 4 ). The other broadleaf forests covered an area of $31.1 \%$ in 2000, which showed progression of Quercus ilex on the massif between 1975 and 2000 (Fig. 4). An increase of mixed forests between 1975 and 2000 , from $1.0 \%$ to $4.8 \%$, and, notably, the progression of Pinus pinaster was observed according to the in situ field observations.

Shrublands/grasslands cover remained stable up to the 19th century, and then increased before decreasing at the end of the 20th century (Fig. 2A). Although shrublands/grasslands showed little net variation, transition matrices revealed a slight progression of shrublands/grasslands to forest, $13.3 \%$ for $1774-1975$ and $14.1 \%$ for $1975-2000$, especially other broadleaf forest, that was counterbalanced by a regression of chestnut forests to shrublands (Fig. 4).

Cultivated areas covered $21.9 \%$ of the region in 1774 and $29.8 \%$ in 1913 (Fig. 2A). After 1913, these activities went into decline, and had ultimately ceased in 1975 and 2000. Transition matrices on the $1774-1975$ period showed that cultivated areas had progressed to shrublands/grasslands, $13.0 \%$, and to forests, $8.2 \%$ (Fig. 4). Urban areas increased slightly over the study period, 0.4 to $2.7 \%$ (Fig. 4).

Between 1774 and 2000, forestation increased by $27.7 \%$ (Fig. $5 \mathrm{~A})$. This increase was characterized by a transformation of shrublands/grasslands and cultivated areas to forests (Fig. 5A). Shrublands also expanded to an estimated $18.4 \%$ of total area, 
Fig. 4. Transition matrices between 1774-1975 and 1975-2000 performed on all the land-cover types for the San Petrone massif. Totals are given for each year and each type as \% of the landscape surface. Bold numbers indicate the maximum relationship between the two maps. Vertical and underlined values correspond to the sum of transition rates within the delimited transition submatrix between the different generic land-cover types.

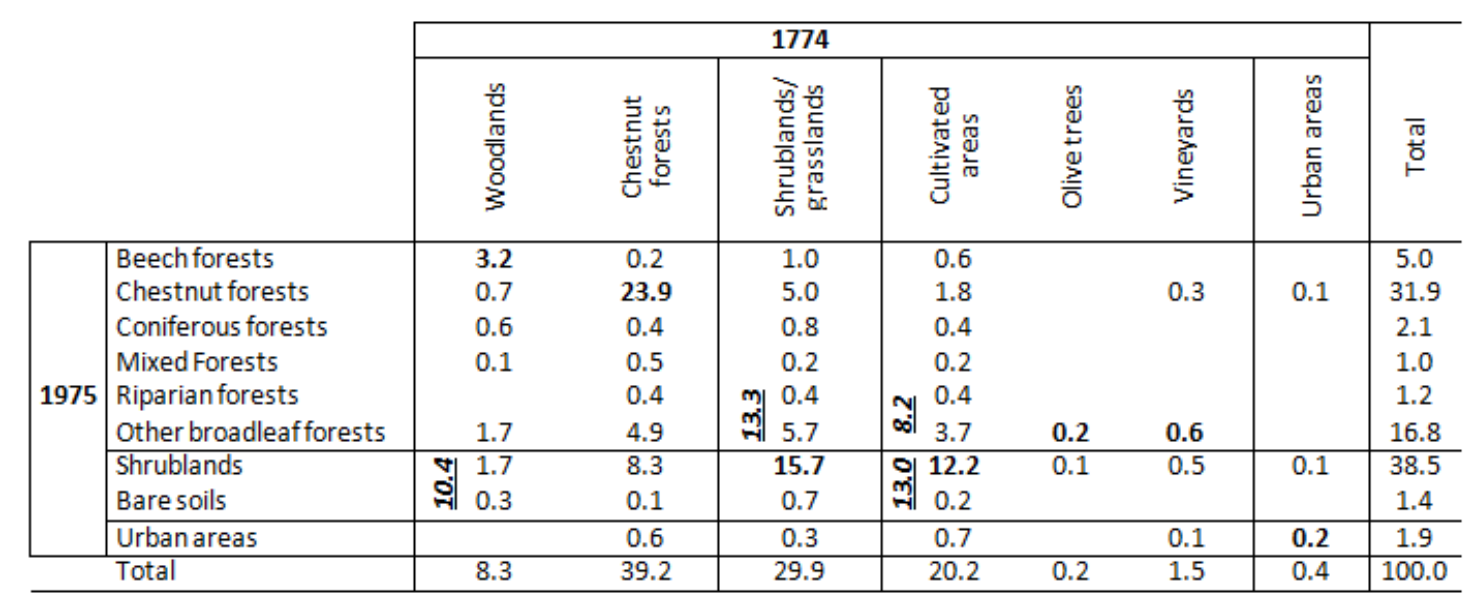

\begin{tabular}{|c|c|c|c|c|c|c|c|c|c|c|c|}
\hline & & \multicolumn{9}{|c|}{1975} & \multirow[b]{2}{*}{$\begin{array}{l}\overline{\widetilde{r}} \\
\text { ठㅁ }\end{array}$} \\
\hline & & 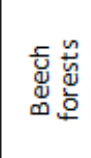 & 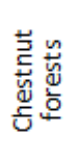 & 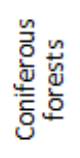 & 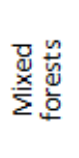 & 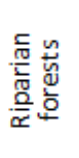 & 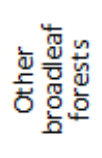 & $\begin{array}{l}\frac{n}{0} \\
\frac{0}{2} \\
\frac{0}{0} \\
\frac{2}{2} \\
\frac{5}{n}\end{array}$ & 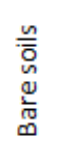 & 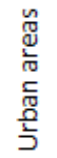 & \\
\hline \multirow{12}{*}{2000} & Beech forests & 4.1 & 0.1 & & 0.1 & & 0.2 & 0.7 & 0.2 & & 5.4 \\
\hline & Chestnut forests & & 6.9 & & & & 0.4 & 0.8 & & 0.1 & 8.2 \\
\hline & Coniferous forests & & 0.1 & 1.0 & 0.1 & & 0.3 & 0.6 & & & 2.1 \\
\hline & Mixed forests & & 0.9 & 0.7 & 0.2 & 0.1 & 1.5 & 1.6 & & & 4.9 \\
\hline & Undifferentiated broadleaf forests & 0.7 & 18.3 & & & 0.2 & 6.0 & 게 5.5 & 0.2 & 0.2 & 31.1 \\
\hline & Other broadleaf forests & & 1.1 & 0.1 & 0.2 & 0.4 & 6.1 & 4.3 & 0.2 & 0.1 & 12.4 \\
\hline & Shrublands & 0.2 & 4.3 & 0.3 & & 0.4 & 2.1 & 22.4 & 0.6 & 0.4 & 30.7 \\
\hline & Mixed Shrublands/grasslands & 0.1 & & & 0.1 & & & 1.3 & 0.1 & & 1.5 \\
\hline & Grasslands & & & & 0.1 & & & 0.1 & & & 0.2 \\
\hline & Bare soils & $\aleph$ & & & 0.1 & & & 0.1 & 0.2 & & 0.5 \\
\hline & Urban areas & & 0.2 & & 0.1 & 0.1 & 0.1 & 1.1 & & 1.1 & 2.7 \\
\hline & Total & 5.0 & 31.9 & 2.1 & 1.0 & 1.2 & 16.8 & 38.5 & 1.4 & 1.9 & 100.0 \\
\hline
\end{tabular}

of which $9.4 \%$ resulted from forest regression. Anthropization was low and localized to areas near major roads. The majority, $51.7 \%$, of the territory remained unaffected by changes in generic land-cover types.

\section{Vico-Evisa region}

Forests experienced a major progression from 1774 to 2000 (Fig. 2B). In 1774, these forests corresponded to heterogeneous land-cover types (Figs. 3B, 6). Woodlands were represented by Quercus ilex at low and midrange elevations and by Pinus sp. and Fagus sylvatica at high elevations. Chestnut forests covered small areas that could not be precisely calculated with the given information. By 1975, forest had progressed to cover $44.8 \%$ of the region (Figs. 2B, $3 \mathrm{~B})$. This progression was mostly caused by an expansion of other broadleaf forests, 20.4\% (Fig. 6). Nevertheless, transition matrices on the 1774-1975 period revealed a regression of forests to shrublands and bare soil, 16.2\% (Fig. 6). As in the San Petrone massif, chestnut forests regressed into shrublands and were replaced by other broadleaf forests. In 2000, forest had increased to $49.2 \%$ of the region (Figs. 2B, 3B). This progression corresponded to an increase of (1) Quercus ilex areas in other broadleaf forests, $20.4 \%$ in 1975 and 26.2\% in 2000, and (2) Pinus pinaster, 8.1\% in 1975 and $10.5 \%$ in 2000 for coniferous forests, $5.9 \%$ in 1975 and $6.3 \%$ in 2000 for mixed forests (Fig. 6). Nevertheless, transition matrices on the 1975-2000 period revealed a regression of forests either to shrublands/grasslands, $9.3 \%$, or to other broadleaf forests, $5.5 \%$ (Fig. 6).

Shrublands/grasslands dominated the region (Fig. 2B). Shrublands/grasslands cover decreased in the 19th century, 
Fig. 5. Maps of landscape dynamics between 1774 and 2000 for the San Petrone massif (a) and the Vico-Evisa region (b).

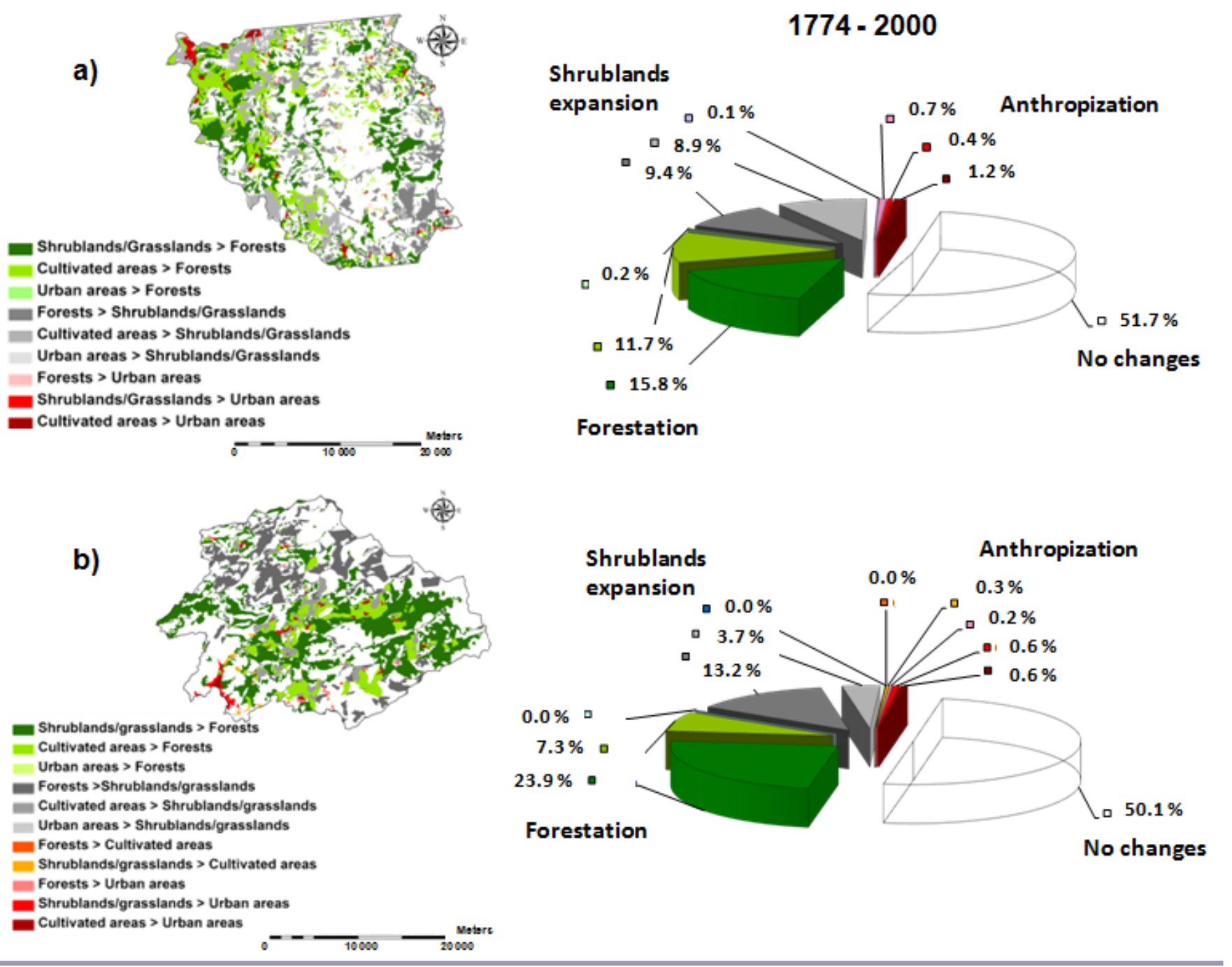

and then increased before decreasing again toward the end of the 20th century (Fig. 2B). Transition matrices showed a major progression of shrublands/grasslands to forests, $23.5 \%$ for $1774-1975$ and $14.7 \%$ for $1975-2000$, notably to other broadleaf forests (Fig. 6).

Cultivated areas covered $11.2 \%$ of the region in 1774 and $8.4 \%$ in 1913 (Fig. 2B). After 1913, these activities went into strong decline, down to just $0.6 \%$ of the region's land in 1975 and $0.8 \%$ in 2000 . Transition matrices on the $1774-1975$ period showed a progression of the cultivated areas to shrublands/ grasslands, 13.0\%, and forests, 6.3\% (Fig. 6). Urban areas remained small in the region, but increased over the study period from $0.1 \%$ in 1774 to $1.5 \%$ in 2000 (Fig. 6).

Between 1774 and 2000, the expansion of forested lands occurred throughout the region (Fig. 5B), reaching an estimated $31.3 \%$, typically driven by a progression of shrublands/grasslands to forests, $23.9 \%$ (Fig. 5B). Shrublands increased to $16.9 \%$, of which $13.2 \%$ resulted from forest regression. Anthropization was low in the region and remained localized to the coastal areas (Fig. 5B). A small majority, $50.1 \%$ of the territory, remained unaffected by changes in the generic land-cover types.

\section{Human population changes}

The human population of the San Petrone massif reached its peak in 1856 at 29,606 inhabitants, i.e., 62.7 inhabitants $/ \mathrm{km}^{2}$, in the 72 municipalities (Fig. 7). The human population of the Vico-Evisa region was generally lower and reached its peak in 1891 at 15,779 inhabitants, i.e., 25.3 inhabitants $/ \mathrm{km}^{2}$, in 22 the municipalities (Fig. 7). In both the study areas, the human population rose from the 18th century to the end of the 19th century, particularly in the Vico-Evisa region where the 
Fig. 6. Transition matrices between 1774-1975 and 1975-2000 performed on all the land-cover types for the Vico-Evisa region. Totals are given for each year and each type as $\%$ of the landscape surface. Bold numbers indicate the maximum relationship between the two maps. Vertical and underlined values correspond to the sum of transition rates within the delimited transition submatrix between the different generic land-cover types.

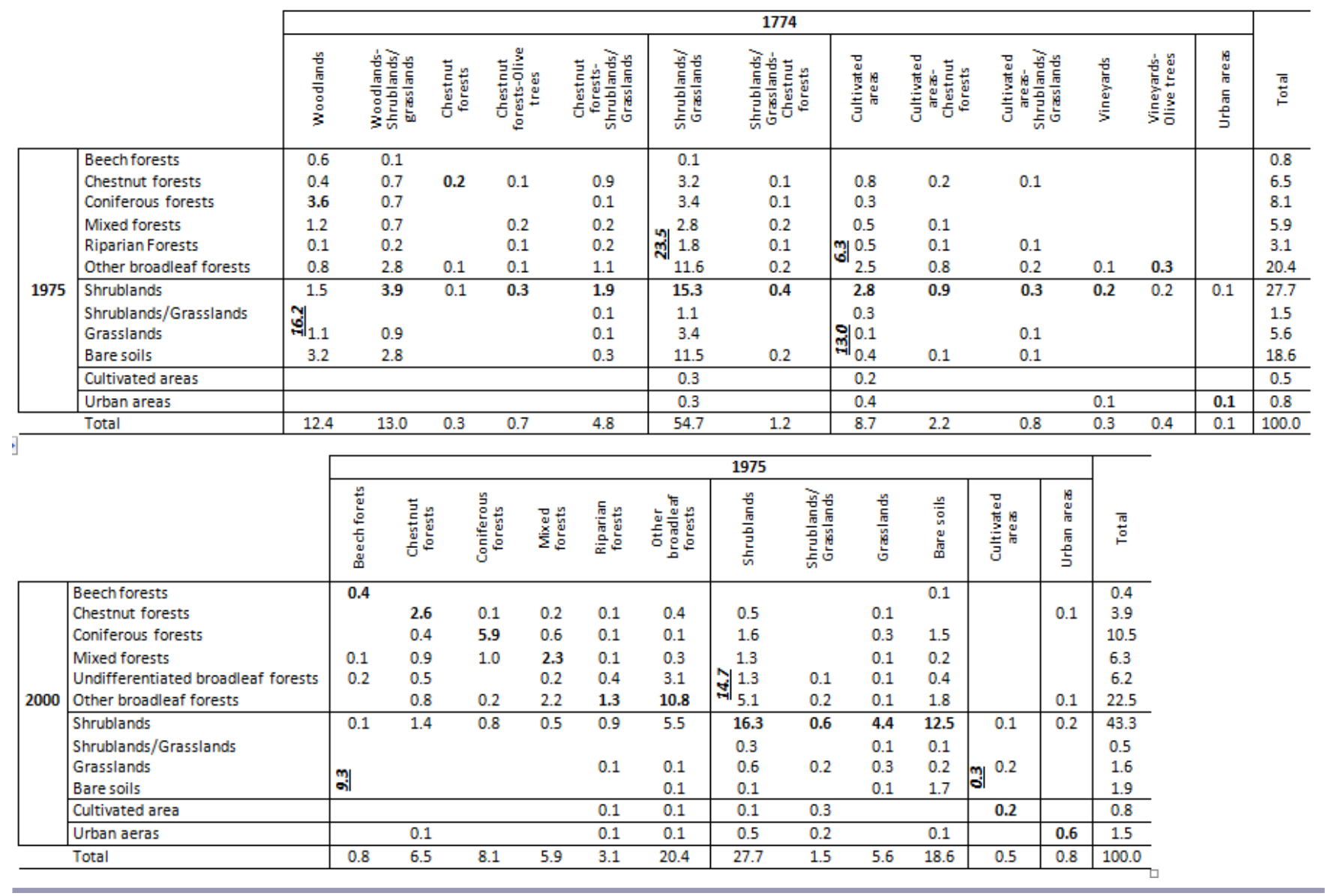

population tripled (Fig. 7). Rural exodus began in the early 20th century with slow population decreases in both study areas. The rate of decline remained relatively constant until the end of the 20th century, except during the First World War, 1914-1918, when the population abruptly dropped. The population decline coincided with the cultivated areas decline and significant reforestation on the two study sites (Fig. 2). After 1990, the population slowly increased in both areas. In 1999, the population of San Petrone massif was 6110 inhabitants, i.e., 12.9 inhabitants $/ \mathrm{km}^{2}$, and the population of the Vico-Evisa region was 3793 inhabitants, i.e., 6.1 inhabitants $/ \mathrm{km}^{2}$ (Fig. 7). Over the course of the study period, there was an increase in the populations of urban areas and a shift of population densities from rural areas to areas near main roads, in the northwest, and coastal areas, in the east, of the San Petrone massif and to coastal areas, in the west, of the Vico-Evisa region (Fig. 8).

\section{DISCUSSION AND CONCLUSION}

In Corsica, long-term vegetation dynamics are directly related to population history. In 1584, the governor of Genua, modernday Genova, ordered all Corsican farmers and landowners to plant four trees yearly, a chestnut tree, an olive tree, a fig tree, and a mulberry tree. Many communities owe their origin and former richness to the ensuing chestnut woods (Perry 1967). The sweet chestnut is a tree species that has attracted particular attention from human populations (Conedera et al. 2004). It is for these reasons that several regions of Corsica are covered by chestnut forests, notably the Castagniccia region (San Petrone massif), which at one point in time was the most populated region of Corsica (Perry 1967). In 1774, chestnut forests covered the largest fraction of wooded areas in the San Petrone massif and the lowest fraction in the Vico-Evisa region. The development of chestnut forests led to the replacement of native Quercus ilex forests that palynoecological analyses show had dominated the island for 
Fig. 7. Number of inhabitants versus time in the San Petrone massif (a) and the Vico-Evisa region (b) over the last 230 years.

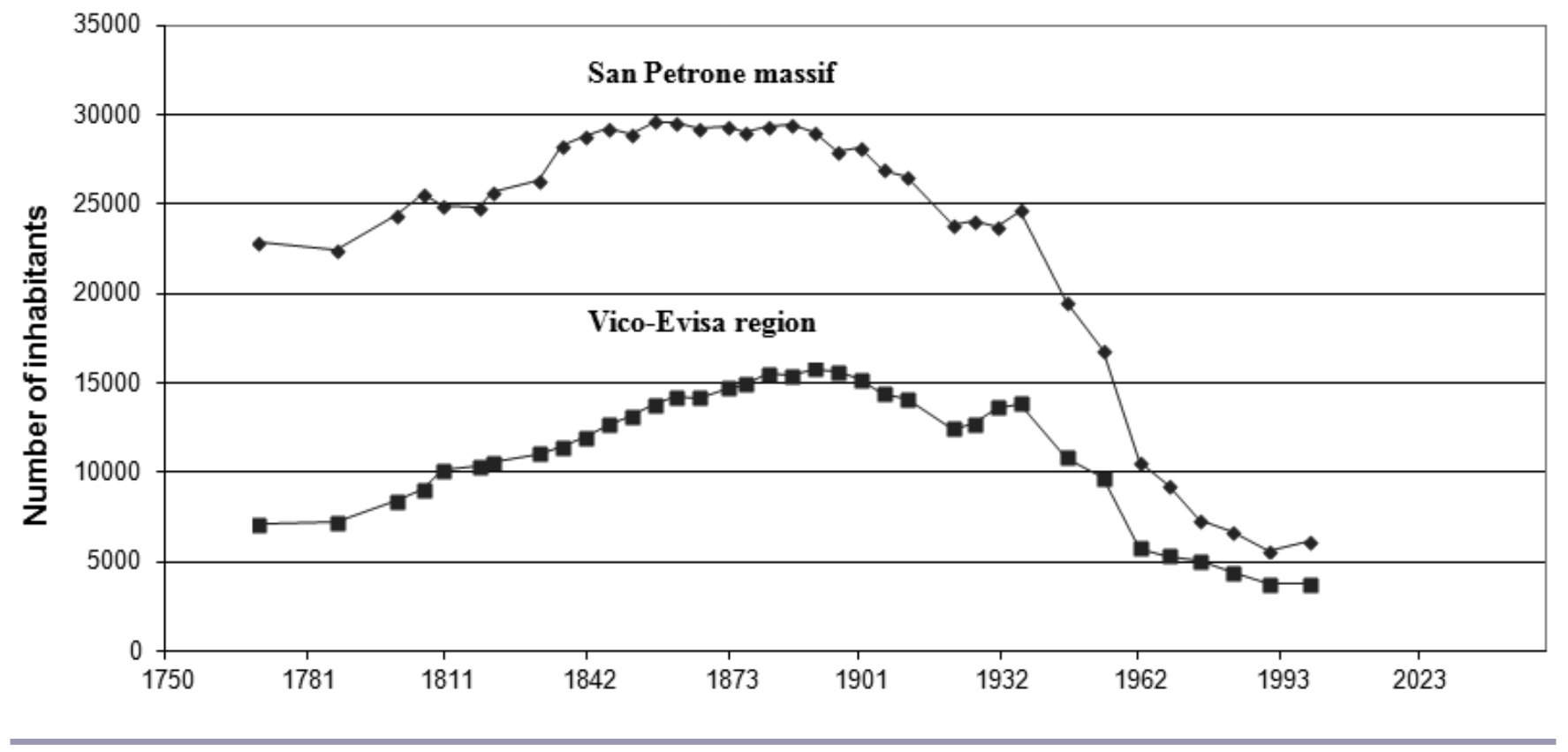

thousands of years (Reille 1992, Carcaillet et al. 1997). Against a background of industrial revolution and two world wars, the population of Corsica declined from almost 300,000 inhabitants in 1890 to 150,000 inhabitants in the 1950 s, through emigration to the mainland and colonies (Lefèbvre 1957). The areas dominated by intensively tended chestnut groves became progressively abandoned because of the rural exodus and related phenomena (Pitte 1986). Other drivers of chestnut forest abandonment were ink disease (Vettraino et al. 2005) and the accidental introduction of chestnut blight around 1920, which seriously damaged chestnut tree quality and yields (Pitte 1986). Over the study period, from 1774 to 2000 , in both study areas, chestnut forests either regressed into shrublands or were replaced by other broadleaf forests. The total area of the San Petrone massif occupied by chestnut forests was halved between 1774 and 2000 , i.e., $-0.09 \% \mathrm{yr}^{-1}$ between 1774 and 1975 and $-1.42 \% \mathrm{yr}^{-1}$ between 1975 and 2000. In parallel, both study areas experienced a significant increase in forest cover between 1774 and 2000, during which forests replaced shrublands and cultivated areas. Between 1975 and 2000, the increase of other deciduous forests was equally strong, i.e., $+3.40 \% \mathrm{yr}^{-1}$ in the San Petrone massif and $+1.14 \% \mathrm{yr}^{-1}$ in the Vico-Evisa region. Our results also showed a significant increase in coniferous forests with $+3.00 \% \mathrm{yr}^{-1}$ in the San Petrone massif and $+0.94 \% \mathrm{yr}^{-1}$ in the Vico-Evisa region between 1975 and 2000. In southern France, in the absence of disturbances, average forest expansion was $1.06 \%$ $\mathrm{yr}^{-1}$ (Debussche et al. 1987), and this highlights comparatively strong forest dynamics for the San Petrone massif. Even though both study sites experienced high levels of forestation, we also observed a regression of forests to shrublands in both study areas. These results could be linked to the occurrence of wildfires in the Mediterranean region (Vález 2000).

The San Petrone massif and the Vico-Evisa region could be considered social-ecological systems. Folke et al. (2010) defines the dynamics and development of complex socialecological systems through three aspects: resilience, adaptability, and transformability. The system is said to have undergone a regime shift (Scheffer et al. 2001) that may be reversible, irreversible, or effectively irreversible, i.e., not reversible on time scales of interest to society. Our study, on long time scales, illustrated the drastic transformation of Quercus ilex forests for the development of agriculture and the cultivation of chestnut and a feedback to mostly Quercus ilex forests following subsequent land abandonment. These results reflect the resilience and high adjustment of the system, even after a regime shift, as notably observed in the San Petrone massif. In the absence of management, chestnut forests tended to be invaded by other tree species, giving way to an evolutionary dynamic toward climax forests, as observed in many European regions in recent decades (Arnaud et al. 1997, Conedera et al. 2000, 2001). However, the strong progressions of broadleaf forests also concern coniferous forests that might have been dependent on rapid colonization, notably through the abandonment of open-land habitats (Quézel and Médail 2003), because the recruitment rate for pines is also associated with declines in local human 
Fig. 8. Maps of population density (number of inhabitants per hectare of urban areas) in 1770, 1975, and 1999 for the San Petrone massif (a) and the Vico-Evisa region (b).

a)

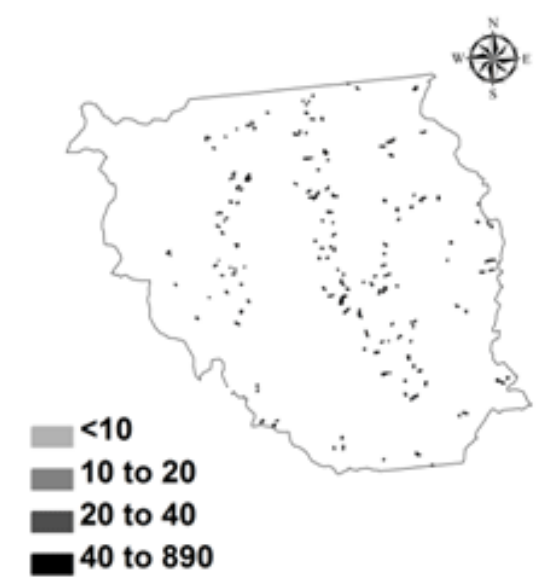

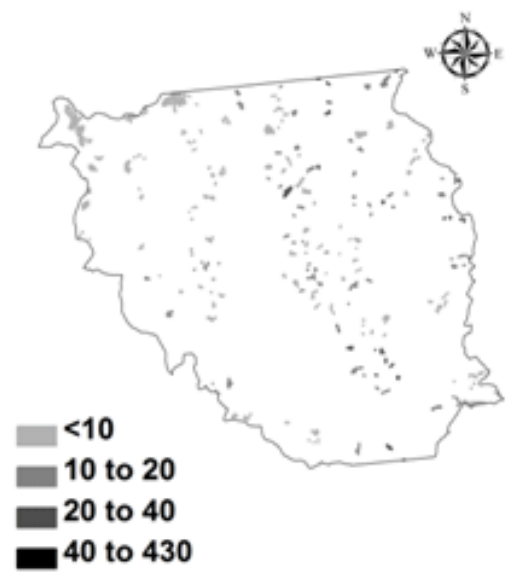

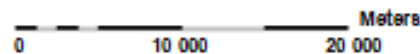

$10000-20000$
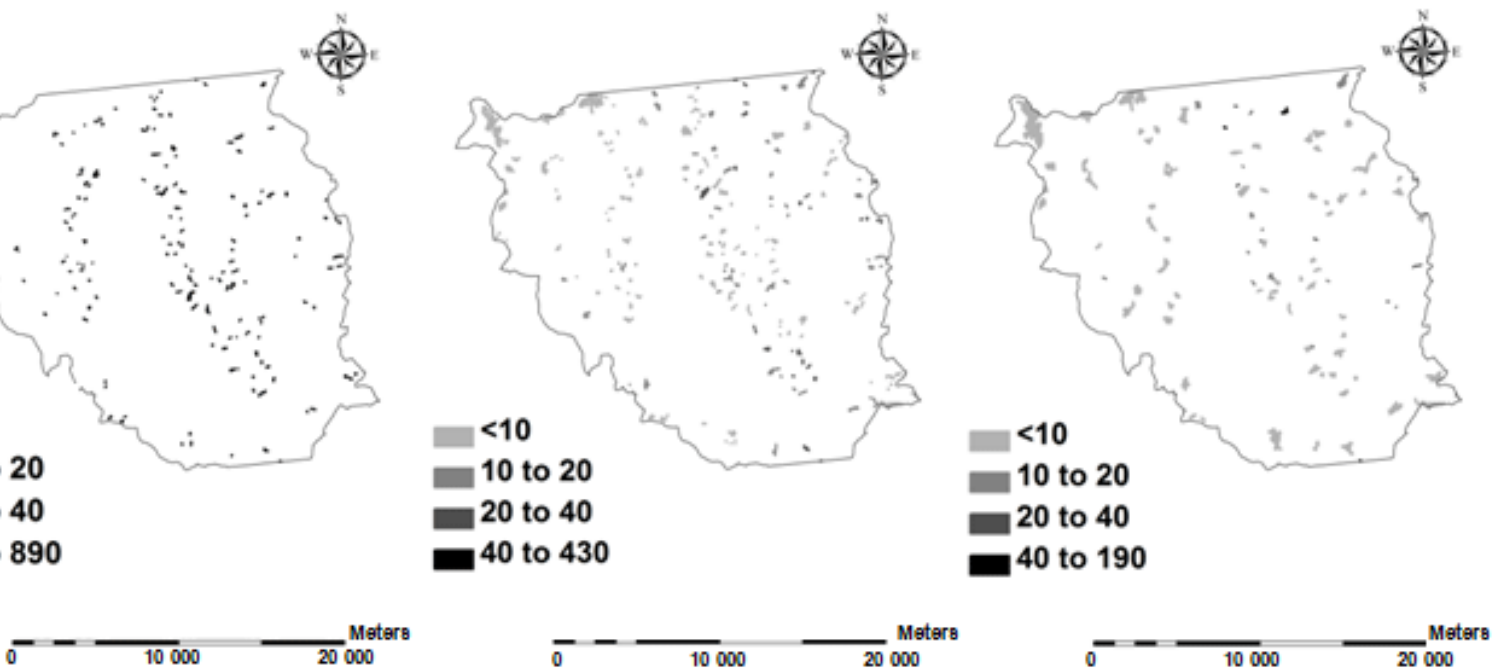

b)
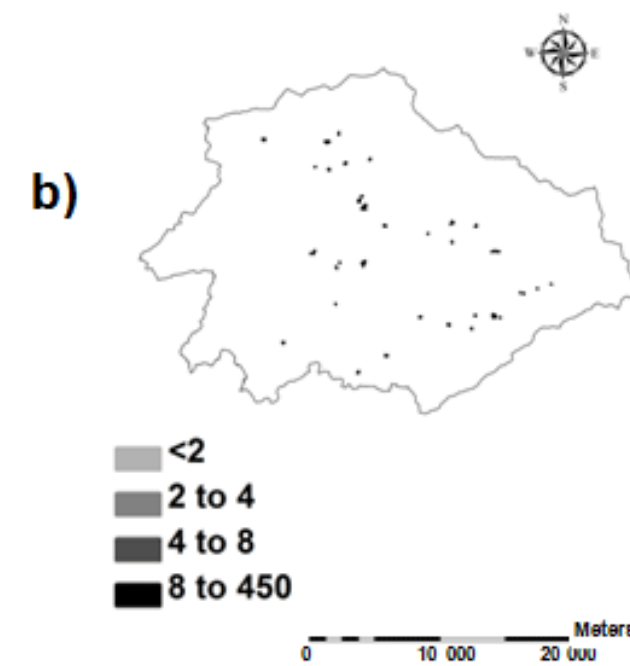

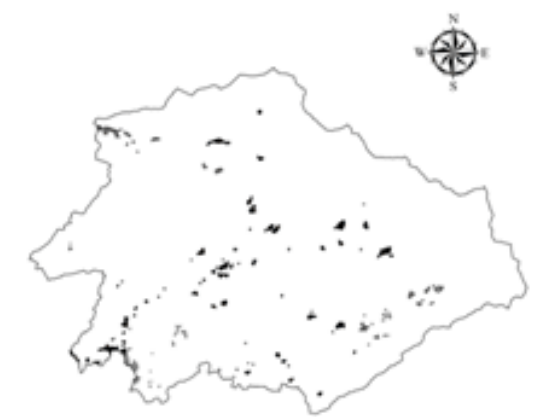

$<2$

2 to 4

4 to 8

8 to 18

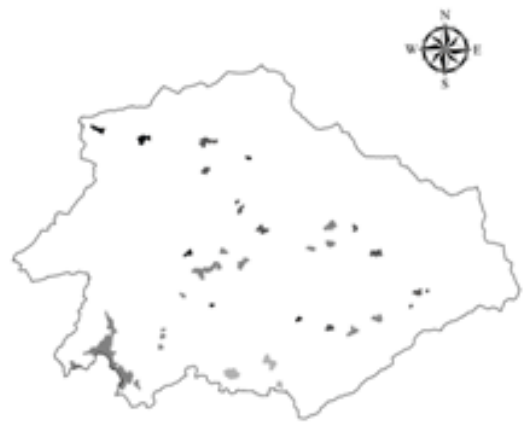

$<2$

2 to 4

4 to 8

8 to 18

population and regional livestock (Curt et al. 2003, Chauchard et al. 2007). The dynamics of a system at a particular scaleof-interest cannot be understood without taking into account the dynamics and cross-scale influences of the processes from scales above and below it. For example, dynamics include disturbances such as forest pest outbreaks or forest fires. Work on resilience suggests that many of the observed shifts, crises, or nonlinearities observed in ecological systems are from processes and structures interacting across scales (Walker and Meyers 2004). Because social-ecological systems are dominated by human action, their adaptability is mainly a function of management. Our study illustrated that the socialecosystems studied may be effectively reversible according to management. Indeed, without constant care, chestnut trees are heavily prone to damage and disease; they slowly decay and stop producing quality fruits, as exemplified by the collapse of most of Corsica's chestnut forests over the 20th century (Michon 2011). However, around 1980, local initiatives started to re-establish the chestnut economy with a compromise between traditions tied to chestnut culture and the modernity of a market economy (Auclair and Michon 2009). Analysis of long-term variability, such as changes in the frequency of events, can provide important insights into how human activity has modified the probability of extreme events and threshold transgressions. 
The alternating regimes of social-ecological systems can have significantly different implications for society, and so, from a purely human point of view, may be considered desirable or undesirable. This desirability can be expressed in economic terms, social terms, or ecological terms (Scheffer et al. 2000). The concept of ecosystem services was used by the Millennium Ecosystem Assessment to link ecological processes to human well-being (Carpenter et al. 2009). In line with the Economics of Ecosystems and Biodiversity definition (Balmford et al. 2008), we use "ecosystem service benefits" to mean the end products that are directly used by humans. Here, human action through massive chestnut introduction in the 16th century has completely modified the ecosystem to build a social-ecological system with very specific service benefits such as the production of food and animal fodder. This ecosystem change helped develop and retain human populations in these areas. The population decline associated with abandoned chestnut trees entails a decrease in specific ecosystem service and in species richness and biodiversity, which correlates closely to a steady increase in the leaf area index of the forest canopy (Gondard et al. 2001). Regime shifts in social-ecological systems can cause rapid yet substantial changes in ecosystem services and human well-being. Regime shifts may be exacerbated by human action or equally by the absence of human action, as was found here. Attempts to optimize a single service often lead to reductions or losses of other services. For example, forested areas provide a variety of extractive and nonextractive goods and services (Rose and Chapman 2003), and a region managed for mining may lose its value for carbon sequestration, flood control, or wilderness and biodiversity protection. In our context, effective decision making, enabling policy makers to gain a comprehensive view of the ecosystem service trade-offs involved, should address the cumulative and synergistic effects of their decisions.

In summary, almost all the landscape changes that have occurred in the study areas were because of changing human influences. The abandonment of farming activities and the accompanying sharp decrease in resident populations has clearly favored natural ecological succession and the degradation of the agricultural landscape. Replacement was essentially marked by Quercus ilex forests, which formed the original forests before human impact, and by the introduction of Pinus pinaster. Corsica currently has relatively low population densities, with only small resident communities, little mechanized agriculture, and poor communications infrastructures (Pitte 1982). In addition, features that attract tourists, such as activities tied to attractive mountain landscapes, are still underdeveloped. However, chestnut producers are striving to revive the chestnut economy, as part of a local reappropriation movement that champions rurality, insularity, and cultural identity as positive values founding local development. Even if it is still in search of sustainability, the 21 st century chestnut economy is experiencing a revival through denaturalization of the ecosystem and socio-technical modernization (Michon 2011). In this context, regional land planning, forest management, and restoration are still limited on Corsica. Our study highlights the value of small-scale approaches for understanding the ecological consequences of land-use abandonment and present and future landmanagement decisions. Because this kind of study needs to be integrated and transferred to landscape and forest managers and decision makers, it is important to develop user-friendly decision support tools (Scarascia-Mugnozza et al. 2000).

Responses to this article can be read online at: http://www.ecologyandsociety.org/issues/responses. $\mathrm{php} / 5556$

\section{Acknowledgments:}

Financial support was provided by the Fédération de Recherche Environnement et Société (University of Corsica, France), and by a grant from the University Complutense of Madrid (Spain). The authors are grateful to the staff of the Archives Départementales du Corse du Sud et de Haute-Corse for their invaluable contribution.

\section{LITERATURE CITED}

Agnoletti, M. 2007. The degradation of traditional landscape in a mountain area of Tuscany during the 19th and 20th centuries: implications for biodiversity and sustainable management. Forest Ecology and Management 249:5-17. http://dx.doi.org/10.1016/j.foreco.2007.05.032

Albitreccia, A. 1942. Le plan terrier de la Corse au XVIIIème siècle. Presses Universitaires de France, Paris, France.

Amandier, L., R. Dureau, L. M. Joffre, R. Joffre, and J. L. Laurent. 1984. Éléments pour un zonage agro-sylvo-pastoral de la Corse. Présentation du programme cartographique. Utilisation des documents et principales applications. Société d'Études Techniques et d'Entreprises Générales/Service Régional d'Aménagement Forestier, SODETEG/SRAF Publ., Région Corse, France.

Arnaud, M. T., J. P. Chassany, R. Dejean, J. Ribart, and L. Queno. 1997. Economic and ecological consequences of the disappearance of traditional practices related to chestnut groves. Journal of Environmental Management 49:373-391. http://dx.doi.org/10.1006/jema.1995.0120

Auclair, L., and G. Michon. 2009. La production durable de biens et services en forêt méditerranéenne: le point de vue du sociologue. La forêt rurale méditerranéenne entre deux paradigmes: étude comparée des constructions patrimoniales de l'arganeraie marocaine et de la châtaigneraie corse. Forêt 
méditerranéenne 30(2):123-132. [online] URL: http://www. foret-mediterraneenne.org/fr/catalogue/id-1177-la-productiondurable-de-biens-et-services-en-foret-mediterraneenne-le-pointde-vue-du-sociologue-la-foret-rurale-mediterraneenne-entredeux-paradigmes-etude-comparee-des-constructions-patrimonialesde-1-arganeraie-marocaine-et-de-la-chataigneraie-cors

Balmford, A., A. S. L. Rodrigues, M. Walpole, P. ten Brink, M. Kettunen, L. Braat, and R. de Groot. 2008. The economics of ecosystems and biodiversity: scoping the science. European Commission, Cambridge, UK. [online] URL: http://ec.europa. eu/environment/nature/biodiversity/economics/pdf/ scoping science report.pdf

Blondel, J., and J. Aronson. 1999. Biology and wildlife of the Mediterranean region. Oxford University Press, Oxford, UK.

Caratini, R. 1995. Histoire du peuple Corse. Criterion, Paris, France.

Carcaillet, C., H. N. Barakat, C. Panaïotis, and R. Loisel. 1997. Fire and late-Holocene expansion of Quercus ilex and Pinus pinaster on Corsica. Journal of Vegetation Science 8:85-94. http://dx.doi.org/10.2307/3237246

Carpenter, S. R., H. R. Mooney, J. Agard, D. Capistrano, R. S. DeFries, S. Díaz, T. Dietz, A. K. Duraiappah, A. OtengYeboah, H. M. Pereira, C. Perrings, W. V. Reid, J. Sarukhan, R. J. Scholes, and A. Whyte. 2009. Science for managing ecosystem services: beyond the Millennium Ecosystem Assessment. Proceedings of the National Academy of Sciences 106:1305-1312. http://dx.doi.org/10.1073/pnas.0808772106

Casta, F. 1993. Paroisses et communes de France. Dictionnaire d'histoire administrative et démographique: Corse. CNRS Édition, Paris, France.

Chauchard, S., C. Carcaillet, and F. Guibal. 2007. Patterns of land-use abandonment control tree-recruitment and forest dynamics in Mediterranean mountains. Ecosystems 10:936-948. http://dx.doi.org/10.1007/s10021-007-9065-4

Conedera, M., P. Krebs, W. Tinner, M. Pradella, and D. Torriani. 2004. The cultivation of Castanea sativa (Mill.) in Europe, from its origin to its diffusion on a continental scale. Vegetation History and Archaeobotany 13:161-179. http://dx. doi.org/10.1007/s00334-004-0038-7

Conedera, M., P. Stanga, C. Lischer, and V. Stöckli. 2000. Competition and dynamics in abandoned chestnut orchards in southern Switzerland. Ecologia Mediterranea 26(1/2):101-112. [online] URL: http://www.wsl.ch/info/mitarbeitende/conedera/ download/Conedera_et_al_2000

Conedera, M., P. Stanga, B. Oester, and P. Bachmann. 2001. Different post-culture dynamics in abandoned chestnut orchards and coppices. Forest, Snow and Landscape Research
76(3)487-492. [online] URL: http://www.wsl.ch/info/ mitarbeitende/conedera/download/Conedera et al 2001

Corvol, A. 1999. Les sources de l'histoire de l'environnement. Le XIXè siècle. L'Harmattan Édition, Paris, France.

Curt, T., B. Prévosto, M. Klesczewski, and J. Lepart. 2003. Post-grazing Scots pine colonization of mid-elevation heathlands: population structure, impact on vegetation composition and diversity. Annals of Forest Sciences 60:711-724. http://dx.doi.org/10.1051/forest:2003065

Debussche, M., J. Lepart, and A. Dervieux. 1999. Mediterranean landscape changes: evidence from old postcards. Global Ecology and Biogeography 8:3-15. http:// dx.doi.org/10.1046/j.1365-2699.1999.00316.x

Debussche, M., S. Rambal, and J. Lepart. 1987. Les changements de l'occupation des terres en région méditerranéenne humide. Evaluation des conséquences hydrologiques. Acta Oecologica Oecologica Applicata 8:317-332.

Durand-Delga, M. 1978. Guides géologiques régionaux: Corse. Elsevier Masson, Issy-les-Moulineaux, France.

Farina, A. 1997. Landscape structure and breeding bird distribution in a sub-Mediterranean agro-ecosystem. Landscape Ecology 12(6):365-378. http://dx.doi.org/10.1023/ A:1007934518160

Folke, C., S. R. Carpenter, B. Walker, M. Scheffer, T. Chapin, and J. Rockström. 2010. Resilience thinking: integrating resilience, adaptability and transformability. Ecology and Society 15(4): 20. [online] URL: http://www.ecologyandsociety. org/vol15/iss4/art20/

Gallart, F., and P. Llorens. 2004. Observations on land cover changes and water resources in the headwaters of the Ebro catchment, Iberian Peninsula. Physics and Chemistry of the Earth 29:769-773. http://dx.doi.org/10.1016/j.pce.2004.05.004

Gamisans, J. 1999. La végétation de la Corse. Edisud, Aixen-Provence, France.

Garcia-Ruiz, J. M., and T. Lasanta-Martinez. 1990. Land-use changes in the Spanish Pyrenees. Mountain Research and Development 10(3):267-279. http://dx.doi.org/10.2307/3673606

Godron, M., P. Daget, L. Emberger, E. Le Floc'h, J. Poissonet, C. Sauvage, and J. P. Wacquant. 1968. Code pour le relevé méthodique de la végétation. Centre national de la recherche scientifique, Paris, France.

Gondard, H., F. Romane, M. Granjanny, J. Li, and J. Aronson. 2001. Plant species diversity changes in abandoned chestnut (Castanea sativa) groves in southern France. Biodiversity and Conservation 10:189-207. http://dx.doi.org/10.1023/

A:1008997625523 
Inventaire Forestier National. 2006. Inventaire forestier départemental: Haute-Corse (2004) et Corse du Sud (2003), 3ième inventaire. Inventaire Forestier National, Saint-Mandé, France.

Kiss, L., F. Magnin, and F. Torre. 2004. The role of landscape history and persistent biogeographical patterns in shaping the responses of Mediterranean land snail communities to recent fire disturbances. Journal of Biogeography 31:145-157. http:// dx.doi.org/10.1046/j.0305-0270.2003.01011.x

Labaune, C., and F. Magnin. 2002. Pastoral management vs. land abandonment in Mediterranean uplands: impact on land snail communities. Global Ecology and Biogeography 11:237-245. http://dx.doi.org/10.1046/j.1466-822X.2002.00280. $\underline{x}$

Lasanta, T., J. Arnáez, M. P. Errea, L. Ortigosa, and P. RuizFlaño. 2009. Mountain pastures, environmental degradation, and landscape remediation: the example of a Mediterranean policy initiative. Applied Geography 29:308-319. http://dx. doi.org/10.1016/j.apgeog.2008.09.006

Lefèbvre, P. 1957. La population de la Corse. Revue de Géographie Alpine 45(3):557-575.

MacDonald, D., J. R. Crabtree, G. Wiesinger, T. Dax, N. Stamou, P. Fleury, J. Gutierrez Lazpita, and A. Gibon. 2000. Agricultural abandonment in mountain areas of Europe: environmental consequences and policy response. Journal of Environmental Management 59(1):47-69. http://dx.doi. org/10.1006/jema.1999.0335

Marty, P., E. Pélaquier, B. Jaudron, and J. Lepart. 2003. Spontaneous reforestation in a peri-Mediterranean landscape: history of agricultural systems and dynamics of woody species. Pages 183-190 in E. Fouache, editor. The Mediterranean world environment and history. Elsevier, Paris, France.

Michon, G. 2011. Revisiting the resilience of chestnut forests in Corsica: from social-ecological systems theory to political ecology. Ecology and Society 16(2): 5. [online] URL: http:// www.ecologyandsociety.org/vol16/iss2/art5/

Molinillo, M., T. Lasanta, and J. M. Garciá-Ruiz. 1997. Managing mountainous degraded landscape after farmland abandonment in the central Spanish Pyrenees. Environmental Management 21:587-598. http://dx.doi.org/10.1007/s002679900051

Mouillot, F., J.-P. Ratte, R. Joffre, D. Mouillot, and S. Rambal. 2005. Long-term forest dynamic after land abandonment in a fire prone Mediterranean landscape (central Corsica, France). Landscape Ecology 20:101-112. http://dx.doi.org/10.1007/ $\underline{\mathrm{s} 10980-004-1297-5}$

Pereira, E., C. Queiroz, H. M. Pereira, and L. Vicente. 2005. Ecosystem services and human well-being: a participatory study in a mountain community in Portugal. Ecology and Society 10(2): 14. [online] URL: http://www.ecologyandsociety. org/vol10/iss2/art14/

Perry, P. J. 1967. Economy, landscape and society in La Castagniccia (Corsica) since the late eighteenth century. Transactions of the Institute of British Geographers 41:209-222. http://dx.doi.org/10.2307/621337

Pitte, J. R. 1982. The chestnut tree in Corsica, symbol of subsistence and cause for civil unrest. Historia 432:140-143.

Pitte, J. R. 1986. Terres de castanide. Homme et paysage du châtaignier de l'antiquité à nos jours. Librairie A Fayard, Paris, France.

Preiss, E., J.-L. Martin, and M. Debussche. 1997. Rural depopulation and recent landscape changes in a Mediterranean region: consequences to the breeding avifauna. Landscape Ecology 12:51-61. http://dx.doi.org/10.1007/BF02698207

Quézel, P., and F. Médail. 2003. Ecologie et biogéographie des forêts du bassin méditerranéen. Elsevier, Lavoisier, France.

Reille, M. 1992. New pollen-analysis researches in Corsica: the problem of Quercus ilex L. and Erica arborea L., the origin of Pinus halepensis Miller forests. New Phytologist 122:359-378. http://dx.doi.org/10.1111/j.1469-8137.1992.tb04241. $\underline{\mathrm{X}}$

Romero-Calcerrada, R., and G. L. W. Perry. 2004. The role of land abandonment in landscape dynamics in the SPA 'Encinares del Río Alberche y Cofio,' Central Spain, 1984-1999. Landscape and Urban Planning 66:217-232. http://dx.doi.org/10.1016/S0169-2046(03)00112-9

Rose, S. K., and D. Chapman. 2003. Timber harvest adjacency economies, hunting, species protection, and old growth value: seeking the dynamic optimum. Ecological Economics 44:325-344. http://dx.doi.org/10.1016/S0921-8009(02)00268-9

Scarascia-Mugnozza, G., H. Oswald, P. Piussi, and K. Radoglou. 2000. Forests of the Mediterranean region: gaps in knowledge and research needs. Forest Ecology and Management 132:97-109. http://dx.doi.org/10.1016/S0378-1127 (00)00383-2

Scheffer, M., W. Brock, and F. Westley. 2000. Socioeconomic mechanisms preventing optimum use of ecosystem services: an interdisciplinary theoretical analysis. Ecosystems 3:451-471. http://dx.doi.org/10.1007/s100210000040

Scheffer, M., S. Carpenter, J. A. Foley, C. Folke, and B. Walker. 2001. Catastrophic shifts in ecosystems. Nature 413:591-596. http://dx.doi.org/10.1038/35098000

Trabaud, L. 1973. Notice des cartes à grande échelle des formations végétales combustibles du département de 
l'Hérault. Centre d'Études Phytosociologiques et Écologiques, Centre National de Recherche Scientifique, Montpellier, France.

Vález, R. 2000. Los incendios forestales en la cuenca Mediterránea, la defensa contro incendios forestales: fundamentos y experiencias. McGraw-Hill, Madrid, Spain.

Vázquez, A., and J. M. Moreno. 1998. Patterns of lightning-, and people-caused fires in Peninsular Spain. International Journal of Wildland Fire 8(2):101-115. http://dx.doi. org/10.1071/WF9980103

Vettraino, A. M., O. Morel, C. Perlerou, C. Robin, S. Diamandis, and A. Vannini. 2005. Occurrence and distribution of Phytophthora species in European chestnut stands, and their association with ink disease and crown decline. European Journal of Plant Pathology 111:169-180. http://dx.doi. org/10.1007/s10658-004-1882-0

Vos, W., and H. Meekes. 1999. Trends in European cultural landscape development: perspectives for a sustainable future. Landscape and Urban Planning 46:3-14. http://dx.doi. org/10.1016/S0169-2046(99)00043-2

Walker, B. H., and J. A. Meyers. 2004. Thresholds in ecological and social-ecological systems: a developing database. Ecology and Society 9(2): 3. [online] URL: http:// www.ecologyandsociety.org/vol9/iss2/art3/

Walther, P. 1986. Land abandonment in the Swiss Alps: a new understanding of a land-use problem. Mountain Research and Development 6(4):305-314. http://dx.doi.org/10.2307/3673371 